ROKSOLANA VERBOVA,

Kyiv choreographic college (Kyiv, Ukraine)

e-mail:r.verbova@gmail.com,ORCID0000-0003-4653-6057

\title{
SELF-IMPROVEMENT THROUGH THE PRISM OF GOD'S COGNITION IN THE POETRY OF VASYL STUS
}

\begin{abstract}
The personalistic ideas of Vasyl Stus in terms of the Christian philosophy are analyzed in the paper. It draws attention to the self-improvement in the context of God's cognition as one of the general problems of the Ukrainian thinker. It elucidates topical issues, which are related to the human internal world and influence on spirituality of a forming person in the research. The general outlines of the Ukrainian poet's work in the context of person's interpretation in his correlation with God are considered. The issue of obtaining personalistic freedom through the interconnection with God is revealed. Furthermore, the personalistic motives of the world and human cognition, where God is the center of the spirituality, are studied. The tendency of appealing to God as the high moral ideal is followed through the works of Vasyl' Stus. The Christian personalism of the poet is depicted via mediation that is considered to be a condition of God and self-cognition. The relations between a man and God reveal their meaning under personalistic perception in the works of Vasyl' Stus. The Christian dimension of life is gained by conversion preceded by a spiritual crisis in the consequence of which a man has lost his positive attitude to the world and his place in it. Personalistic method of cognition became theoretical and methodological base of the study. It is recognized to be a universal mean of human and reality cognition that expresses the gist of such dimension as theism, has its instrumental status in personalism, having considered a man in the perspective of a unique personality as well as having determined the paradigmatic frame to personalistic conception in general.
\end{abstract}

Key words: Christianity personalism; self-improvement person; self-cognition person; personalistic ideas of $V$. Stus; personalizing processional; person being; God; the tragedy of the person.

\section{Introduction}

Vasyl' Stus is the prominent figure of Ukrainian philosophy of the 20th century. In our view, he should be considered as a representative of Ukrainian Christian personalism which permits to reconsider human being in the world and his interconnection with God in the sphere of Ukrainian philosophy. There were the philosophical reflections of Vasyl' Stus who was a member of the Sixtiers, and according to Leonid Plusch, represented "new esthetics that had knocked its ideas and views" (Scharhovska, 2011: 25).

The issue of self-improvement via God's cognition in the poems of V. Stus is rather urgent. It sharpens the theme of human consideration in Ukrainian philosophical thought and highlights the issues connected with the human internal world and spiritual influence on human development in the works of the Ukrainian writer reviewing from the perspective of philosophy of Christian personalism. The letter refers to internal value human attitude to the world, God, spiritual and moral personal values. V. Stus reveals the Christian human attitude to the real world, to a person himself.

The issue of self-improvement via God's cognition in the poems of V. Stus was studied by I. Dzuba, M. Kotzjubynska, V. Marynchak, M. Mościszko, L. Tarnashynska, Yu. Shevel'ov, Yu. Shelech. The paper of V. Marynchak "The Christian Dimension of Being" (Marynchak, 2010), where the world's and self-perception is considered via tragedy of Stus's lyrics, is rather useful. A person can escape tragedy owing to God's cognition, moreover, self can be known via God. I. Dzuba in his article "A Carver of Personal Spirit" (Dzuba, 2018) analyzes the identity issue in the works of Stus through tragedy of being of every particular person. M. Mościszko in the study "The Surrealistic Image of Hell in the Poetry of V. Stus based on "Jolly Cemetery" collection" addresses to the image of hell in the light of imperfect human understanding of his assignment in the real world, absurd self-knowledge (Mościszko, 2019). Generally, there are a lot of such endeavors to study personalistic ideas in the work of Vasyl' Stus, however there is no complex analysis of Christian references of personalism intrinsic to the Ukrainian poet in one study. The abovementioned fact has influenced on the article writing.

The aim of the issue is to outline the dimension of self-improvement through God's cognition in the personalistic work of V. Stus, where a person is considered in the light of his connection with God, wherein after having known God, he can assert and realize himself. The goal prescribes the following objectives: to study relations between a man and God in the work of V. Stus according to Christian personalism; reveal the issue of personal freedom via God's knowing; prove personalistic dimensions of the world and person's cognition, where God is a center of spirituality.

\section{Methods}

Personalistic method of cognition became theoretical and methodological base of the study. It is recognized to 
be a universal mean of human and reality cognition that expresses the gist of such dimension as theism, has its instrumental status in personalism, having considered a man in the perspective of a unique personality as well as having determined the paradigmatic frame to personalistic conception in general. The Christian personalism as a direction reflected the sense of relations between human and God was analyzed by E. Brightman in "Personality and Religion" (Brightman, 1934). His monography depicted the way of human personalistic representation and connected its detailed description with Christian personalism. The theism fundamental principle of similar God and human's being, vividly expressed in the poetry of V. Stus, explicitly becomes the base of the philosophical conception of personalism in the sphere of moral and ethical issues as well as in social and philosophic doctrine (Mogheyko, 2001: 740).

The method is considered as the main for human problem analysis in the poetry of V. Stus, its connection with society and the higher perfectness - God, as well as for the study of the similar issues in Ukrainian philosophy (Chuiko, 2008: 28).

The method of historicism is applied for the issue of self-improvement through God's dimension. It is in the analysis of Ukrainian philosophy representatives' issues in the light of contemporary consideration aimed at the comprehensive research of the subject of our study.

The method of categorical analysis incorporates the quality specific of the study subject as the categories permit to characterize the quality of object of knowledge.

Moreover, the biographical method is described in the paper. It provides the theoretical ground for modern historical-philosophical science. The unity of biography and work of the Ukrainian thinker, its impact on Vasyl' Stus's personalistic ideas is analyzed. Furthermore, the method is used for clarification and specification of a poetic school the poet belongs to.

The phenomenological method occupies a prominent place; it reflects the study subject's outlines and facilitates to acknowledge the spiritual processes formed V. Stus's personalistic worldview. The gist of personalism as a phenomenon regarding being, development and selfimprovement is studied owing to the method.

The hermeneutical method for the texts' interpretation is applied for self-improvement study through God's cognition. Due to the method, the paper contains several original aspects of awareness of the problem of human and social, human and God, persons and individualities' relations as well as their commonality and difference regarding human.

Owing to the applied methods, the main thesis of the study is: what is a way of God's cognition and how the issue is considered in the poetry of Vasyl' Stus.

\section{Results and Discussion}

One of the central issues of personalistic philosophy of $\mathrm{V}$. Stus is the balance between cognition and selfcognition in the context of Christian attitude to the world. "Your internal world, your personal light is a method of "other souls'" cognition" - according to the Ukrainian poet. L. Plusch, who states that for V. Stus, self-cognition is possible only as "You-cognition": "Stay and observe how many faces are near you, they are like halos..." (Plusch, 1986: 106). The lines have one of the deepest bases of Christian personalism of the Ukrainian thinker: "Look carefully, there is the light of human souls, "like halos" near you. As the icon-painting images are becoming to be visible on the faces, created "in the image of God". As you are. Nevertheless, you cannot see your halo. It is an image". The personalistic dimensions of the words depicted in the following: "Stay and observe". They are modified words of Jesus addressed to the dead daughter of Jairus: "Girl arise..." (Plusch, 1987: 287).

V. Stus interprets the action "arise" as something that includes the action itself and the image of resurrection of every particular person: "Be yourself, be filled and observe. Only when you have reached this state, you exist and can notice others. And via them you can see your soul" (Plusch, 1987: 287-288). According to V. Stus such personalistic principle of self-cognition meant opposition to the world of evil as well as to himself (Dzuba, 2018: 8). I. Dzuba encouraged to notice his internal contradictions: "selfcontradictory..."; "quite alone, I am against myself...". Nobody could accuse him in nothing, he was the moral authority, and still he blamed himself and demanded a lot from himself. His strong will won his heart and mind, he watched himself. Sometimes, he appealed to himself in the moments regarded by him as the moments of weakness and lifted personal spirit by his own words (Dzuba, 2018: 8):

\section{"О Боже, тиші дай! О Боже, тиші!}

Ця самоокупація душі,

оця облуда людяності, може,

страшніша за злочинство, ия жага

самотерзання в вимерлому світі

напівречей-напівлюдей (Stus, 2008: 56) 1 .

Here the personalistic dialogue between a man and God can be followed. The dissident referred to God as for the highest moral ideal presented in the human internal world (Borodinova, 2011: 127). According to the context Stus wrote that religion was a movement around and in him (Kvit, 1999: 44).

In addition, mediation is worth considering as a state of God's cognition by every particular man in the context of Christian personalism of V. Stus. L. Plusch assumed that the Ukrainian poet published the verse "Meditation" in the collection "Winter Trees" with the aim to depict the sense of personal loss in the world and universe, hence in the dream world. Due to the Ukrainian researcher, Stus's meditation, as a psychological action, is a method of penetration into the human internal world with an intensified focus on some actions, with full experience and savoring (Plusch, 1988).

It can be noticed that having personalized the world, V. Stus introduces the concept of "voice of the Vedas" in the poem "The Stars in the Sky" regarded as the voice of the poetical universe, logo-cosmos that is isomorphic to the world of inner self and everything that is beyond it, hence, it is a voice of nation (people) and God:
"...Світ у мені. У світі я.
I сльози радості прозорі, як небеса, як ти, моя поснула земле, як дорога, що викреслилась посеред, щоб од людини і од Бога я міг почути голос Вед" (Stus, 2008: 433).

The poetry of V. Stus is an adequate voice of the poet to the Vedas, and abovementioned meditation is a way to

\footnotetext{
${ }^{1}$ Hereinafter, the verses are given in the original.
} 
hear a voice of national, collective spirit in a personal soul and via it to understand the national word, Logos - the voice of God, universe. Penetrating into the depth of personal self and collective outside knowledge (due to Stus - "indirect knowledge"), a man gains the knowledge, the sacred knowledge. The knowledge refers to a personal, national soul as well as to the universe... Thus, a man obtains knowledge about God (Plusch, 1988). The poorer the external world, the higher spiritual level will reveal. It is demonstrated in the dynamics of birth of psychological actions, in the treasure of thoughts, moods and feelings' transformations and appeals to God (Schevelov, 1986: 22). The historian and psychologist Nila Zborovska concluded that $\mathrm{V}$. Stus regarded his way as a courageous way of pain that was similar to the way of a son of God and son of the nation inspired by the holy God's will (Solovei, 2016: 100). The integrity of life is split into internal and external, wherein the internal life is a reflection of external and condition of its existence. Everything external is considered to be hostile and aimed at overcoming a lonely person and the single claim for himself and reason for a conflict is his eager for humanity. Someone from two is inappropriate - whether a poet or the world. The internal world's infinity is demonstrated as rejection of ugliness of the external world. "God was born in me..." (Stus, 2008: 400), - Vasyl' Stus wrote. He did not permit to disappear into reality, nevertheless, in the moments of weakness he wanted to leave me "for my salvation by the dark of submission". The most terrible thing would happen in that moment. Grave tranquility among life meant loss of my soul - the factual death (Kvit, 1999: 22).

$\mathrm{He}$ is my salvation and I solemnly proclaim: save me God. Please, save me for a moment and then having awakened, I will save myself (Marynchak, 2010: 236-237). According to the dissident, soul's salvation is possible only via personal efforts (Punina, 2016: 54).

Consequently, V. Stus considers that such self-penetration is reflected in the internal world's establishment that creates your personality, work with the eager for searching personal real identity. The author is exceptionally interested in the internal world. The subjective feelings of a lyrical character are absolute as his solely inner self is unique value under the system of total personality elimination (Stus, 1992: 37, 58).

The issue of V. Stus's lyrics is predominantly connected with the search of self, soul and self-identity, and in the cases of its loss to restore it again, enduring "the pains of self-denial at the moment when I have already become myself" (Marynchak, 2010). According to Stus, it is depersonalization of soul: "Quite alone, I am staying against myself. Night. Darkness. Only weak cry rises to the sky" (Stus, 1990: 319). One of the most crucial personal desires is to return to self, personal creation, God (Marynchak, 2010).

The Christian personalism in general, or rather consideration of God's cognition issue in the works of the Ukrainian poet is revealed through the symbol of faith, which according to A. Horbach, is in creation of bread of living, hence, the community life is founded via selfsacrifice, understanding of personal mission that is able to maintain inner and outer spiritual harmony and through this to be honest in front of God. We should consider the extremal conditions of the poet's living, and this is not a brief space journey. The flight for him is mobilization of psychological energy, courage, balance for a short time, and later for decades, for the whole life (Horbach, 1986:
111-112). The Ukrainian poet analyzes faith in the light of its impact on a person: "Every caused trauma of faith is much more severe than the separate economic flaws. The trauma of faith leads to senile, villainy; it destructs the most honest people, internally ruins them, brings up cunning, accurate calculation and unrivalled slippery. "It is impossible to be honest! Who needs your stupid honesty?" the conditions cry. You have to love unless it is prescribed, believe so deep that tomorrow you can painless reject your faith, hate without passion, that tomorrow you can be careless, when you don't love, etc." (Stus, 1992: 84).

V. Marynchak considers that only several particular theses can be taken from the work of the Ukrainian poet where his Christian attitude to the world, human and author position is realized in general. Nevertheless, all moments in total create the general view of V. Stus on the relations between a man and God that is also crucial in the individual author's reflection and in establishment of the general personalistic perception inherent in a modern person connected with ethnical, historical space and time (Marynchak, 2010: 232). Initially, it should be mentioned that the Christian dimension of life is gained by conversion preceded by a spiritual crisis in the consequence of which a man has lost his positive attitude to the world and his place in it. The world as well as his personal state causes rage, indignation, disgust. The continuance of being in the former state becomes unbearable; a man endures an internal spiritual catastrophe. V. Stus endured such catastrophe at the level of personal and world's perception in full. In October 1968, he wrote (Marynchak, 2010: 232):

"Ось так живу: як мавпа серед мавп
чолом прогрішним із тавром зажури
все б'юся об тверді камінні мури,
як їхній раб, як раб, як ниций раб.
Повз мене ходять мавпи чередою,
у них хода поважна, нешвидка.
Сказитись легше, аніж буть собою"

(Stus, 2008: 28).

Consequently, having obtained personal cognition, a man reveals God and can get closer to Him. Similarly to T. Shevchenko, V. Stus highlighted the impossibility to solve "transcendental issues" in that state of a country. The spiritual emptiness of a system was an obstacle: "How heavy are the rocks of global emptiness, and you, the predecessors track fear of the hidden desires..." (LysenkoKovalova, 2008: 221-222). The sole thing the poet believed in to the end was his own way to God and people regarding whom he said: "... a few of us. A small company aimed at prayers and hopes..." (Lysenko-Kovalova, 2008: 222). It was worth remembering that $\mathrm{V}$. Stus endeavored to "reveal the highest mystery by heart without losing his spirit" (Lysenko-Kovalova, 2008: 222). Still, initially he appealed to God with the request of salvation in order to have an ability of saving himself later (Kvit, 1999: 47). In this way, the poet highlights the mystical experience of internal spiritual processes. The personalistic God's cognition is characterized by active-reflective mode determined by orientation on self-development and "penetration" to self (Lysenko-Kovalova, 2008: 222). He depicts God as a subject of action via personal detailed explanation in his works (Markina, 2014: 224):

"Господь усміхнувся. Він

з радістю чує:/ ще серце людське не занурилось в гpix" (Markina, 2014: 225) 
By words of S. Soldatov (a friend of the Ukrainian poet in prison), V. Stus was a deeply religious person (Soldatov, 1986: 123). He personalized God and claimed that God should revenge for him. God was my inner self; he was in me, in my soul. The poet Stus as a personality was God because he was born in me. And only then the steps of God were heard in me, in my soul (Plusch, 1988):

"Народжуваний в мені Бог

Хоче вийти геть,

щоб згасла свічка болю. Щоби тьма

впокорення мене порятувала

Інобуттям. Іножиттям. Найменням

уже невласним: ось він той загал,

яким кермує той шалений Бог,

котрий в мені воліє народитись"

(Stus, 2008: 433).

According to the complexity of transformation processes occurred in Stus's consciousness, the following scheme can be designed: the loss of self; rejection of the struggle against the external evil; seclusion; self-penetration; birth and development of new "self" opened to the direct dialogue with own consciousness (LysenkoKovalova, 2008: 222). A real believer can accept the fact of holiness as the reality, thus, he is able to communicate with God. V. Stus truly believed in God, however, "he had just reached the gates of Eternity and knocked" (Babenko, 2006).

Such personificated dialogue of a person with God determines a range of problems: meanness and spiritual rejection, slavery and freedom (Christianity is the religion of freedom), and one of the most crucial issues for Stus is being himself (Marynchak, 2010: 232-234).

According to $\mathrm{G}$. Marsel a way to truth (that is a synonym of a right chosen way) leads through the acts of inner selfconsciousness. Particularly, owing to inner experience, being is a process of eternal renewal. The same is regarding $\mathrm{V}$. Stus. Having experienced the false of personal being via unnecessary relations with the external world ("it seems to me that I am not living, but someone else is living instead of me in my body"), the poet endeavored to find a formula of living after his forced separation from the world. A solution becomes an endeavor to accept personal being as a mystery that is to be revealed. Thus, a range of themes and issues were chosen by V. Stus that determined his new worldview. Yu. Sherech wrote: "the themes and issues are exceptionally the roads to the internal world, to a diary of soul, to the unsent letter to others regarding inner self" (Lysenko-Kovalova, 2008: 219-220).

Such relevance of personal being transfers into a state of full spiritual freedom as a mean of peculiar meditation (Onikiyenko, 2012: 68), which is mentioned above as a personalized pray to God. V. Stus depicted his characters worldview through their personal internal freedom (Barabanova, 2008: 316), that revealed his attitude to God. Freedom is self-realization, however, such realization cannot be without personal appeal to God. Human being becomes precise and transparent due to the freedom; a person can find his self. This is the main principle of personalism. Freedom is an act of faith, transparency, selfcontrol, total liberation of responsibilities along with the total acceptance of them (Cheremska, 2006).

Freedom is reached via continuous being that is not transformed under the external necessity, but under the internal strong will. Even having lost any connection with the external world, a man can save his spirit owing to mastering his internal world (Onikiyenko, 2012: 70). Moreover, the world of V. Stus is subjective to a greater extent: Whether the world accepts me as I am from my birth or it will kill me, but I have never conceded. The internal confidence in his right road is stronger than the objective circumstances: "I am alone. And it is my nagging pain" (Stus, 1992: 8).

Furthermore, a free man is not inserted in any routine frames; he is restricted by nothing and is free to choose his way wherein he is completely responsible for his choice. As well as V. Stus was responsible for his choice, carrying his burden throughout life. Freedom is reflected in the ability of being self, being a person (Hlushkovetska, 2011: 125, 127). V. Stus focused on freedom that hid a person. Due to O. Barabanova, such freedom in the poetry of V. Stus was not transferred into a choice with more or less consolation, but was represented as a necessity in a form of consumption. Consumption became a responsibility, the most crucial from all responsibilities. The freedom of consumption was presented as a fundamental connection between the personal desires and rational social system. Such type of freedom as aesthetic taste combines responsibility and rationality: persons engaged by a society primarily as consumers and later as manufactures, therefore, the social tendency establishes a responsibility to consume which founds the trends for industry that works according to the reasonable schemes (Barabanova, 2008: 321).

Due to $\mathrm{O}$. Barabanova, the central issue of the poetry of Vasyl' Stus was the way of aesthetic freedom, its understanding as a main decent goal of all intensive efforts, a man should aim at; a goal that is not required any additional explanations (mind arguments). Therefore, a man can just grasp it in his direct emotional experience, the highest level of which is the esthetic feeling of unity with nature. The artist severely felt the ambiguity of physical human being and like a creator wanted to demonstrate clearly his creative impulses, materialize inspiration; nevertheless, the physical form limited him without any possibility to make a loud statement (Barabanova, 2008: 321).

The Ukrainian poet analyzed the nature of choice in the context of freedom, claiming that his poetry was the poetry of choice, evidence of choice, illustration of choice and a choice itself. Whole world was divided into good and evil according to the Christian principle; and the poet had to make his choice and accepted any side. V. Stus made his choice in favor of good and did it for the sake of the highest goal - an ideal, which was real for him the same as the cynicism of his environment. Nevertheless, determination did not negate complexity of the world. The poet is considered to be a researcher of limits in his personalistic interpretations (Kvit, 1999) that is expressed in the lines of his verse:

"Тільки бо грішний про святощі знає, тільки бо грішному стати святим, тільки межу заступивши, відчуєш, тільки упавши, пізнаєш себе" (Kvit, 1999).

The idea of infinity is embodied into an image of freedom that is simultaneously a cosmic substance and the highest spiritual dimension in the poetry of V. Stus. Freedom is a mean of reaching all global ideas that a man-creator obtains and embodies into all physical forms regarding the traditions of human culture.

The idea of freedom is not new in the history of culture. The place of freedom in human formation is the ultimate 
truth and inexhaustible source of poetical epiphany from the view of the poets. That was the freedom that the soul of Vasyl' Stus desired, filled with grief, intrinsic to his soul, of impossibility of reaching the dream by a true artist (Barabanova, 2008: 321-322). He emphasizes the ethical human dimensions in his comments, namely, any delicious food is not important for a man, uniquely, "the will is the highest notion in the world, it is everything that a person needs" (Stus, 1994: 350). A person is at the intersection, where he realizes himself as individuality, as a creator of his personal "living" space (Tarnashynska, 2001: 151). This is an indication of the ideas of Christian personalism in the works of Vasyl' Stus.

\section{Conclusions}

The Christian personalism of Vasyl' Stus is presented in the light of his experience of human fate, catastrophe of human being, desire of freedom and consequently, the possibility of communication with God. The tendency of applying to God, to the highest moral ideal presented in the human internal world, where a personalistic dialogue between a man and God occurs, is followed. The philosophical self-penetration can be noticed in the internal world's creation that formed a man, his work, and desire to find his true self. The author is exceptionally interested in the internal world: its "initial" and "eventual" stages. Personification is demonstrated through the subjective feelings of a lyrical character presented at the absolute level, thus, his inner self is the unique value under the system of total personality elimination. Human selfimprovement is possible only within God's cognition. A man should make his choice whether to keep God's prescriptions, maintain his internal world and enhance his life or take other side of evil and lose his personalistic dialogue with God. God's cognition is connected with the search of inner self in the world, with the finding of human soul, with endeavors of maintaining personal uniqueness, unless it should be renewed.

\section{REFERENCES}

Babenko, V. (2006). Tradytsiya i novatorstvo filosofsko-svitohlyadnyh aspektiv tvorchosti V. S. Stusa. Moloda Natsiya. Kyiv: Smoloskyp. № 1. Retrieved from: http://stus.kiev.ua/ konferencija.files/babenko-dopovid.zip (In Ukrainian)

Barabanova, O. (2008). Poetyka peyzaghu Vasylya Stusa. In S. V. Myshanych (Ed.), Aktualni problem ukrainskoyi literatury i folkloru: nauk. zb. Donetsk: Kasssiopeya. № 12: 315-322. (In Ukrainian)

Borodinova, M. V. (2011). Chrystyanski obrazy, motyvy v poeziyi V. Stusa. Naukovi zapysky Natsionalnoho universytetu Ostrozka akademiya. Seriya Filolohichna. Vyp. 21: 125-131. (In Ukrainian)

Brightman, E. (1934). The personality and religion. Boston, 160 (In English)

Cheremska, O. (2006). Filosofskyi aspect problemy avtentychnosti buttya u tvorchosti Vasylya Stusa. Moloda natsiya: almanah. Kyiv: Smoloskyp. № 1 (38). Retrieved from: http://stus.kiev.ua/ stusoznavstvo.htm (In Ukrainian)

Chuiko, V. (2008). Metodolohichna funkciya personalizmu v suchasnyi filosofii. Naukovyi visnyk Chernivezkoho universytetu. Chernivtsi. Vyp. 412-413: 27-31. (In Ukrainian)

Dzuba, I. (2018). Rizbjar vlasnoho duhu. In O. Solovii, O. Punina (Ed.), Stusoznavchi zoshyty: Naukovyi almanah. Zoshyt chetvertyi. Vinnytsya: Prostir Literatury, 128: 5-23. (In Ukrainian)

Hlushkovetska, N. (2011). Ekzystentsyinyi dyskurs tabirnoho epistolariyu Vasylya Stusa. In H. L. Tokman (Ed.), Teoretychna i dydaktychna filolohiya: zb.nauk.prats. Kyiv: IVZ Derghkomstatu Ukrainy. Vyp. 10: 121-130 (In Ukrainian)

Horbach, A. (1986). Vasyl Stus u spohadah ta vidhukah chuzhomovnoyi presy. Suchasnist. Ch. 5(301): 111-113. (In Ukrainian)

Kvit, S. (1999). Chorne sonce z biloyi nochi potoibichnosti. Svitovyd. № 1: 44-57. (In Ukrainian)

Lysenko-Kovalova, N. (2008). Svitospryinyattya diysnosti kriz pryzmu poeziyi Vasylya Stusa. Actualni problemy ukrainskoyi literatury i folkloru. Donetsk. № 12: 214-223. (In Ukrainian)

Markina, A. M. (2014). Boh i Hospod yak chynnyky hudoznyoho svitu Vasylya Stusa. Visnyk Harkivskoha nazionalnoho universytetu imeni V. N. Karazina. Seriya Filolohiya. 71 (1127): 223-227 (In Ukrainian)

Marynchak, V. (2010). Chrystyanskyi modus buttya. Gazeta Nasha Vira. № 8. (In Ukrainian)

Marynchak, V. (2010). Recepciya i vidtvorennya chrystyanskoho modusu buttya $v$ lirytsi V. Stusa. In V. Marynchak, Nastoyatelnost skazannoho. Katastroficheskoye - socrovennoye sacralnoye $v$ iskusstve slova. Kharkiv: Prava ludyny: 231239. ( In Ukrainian)

Mogheyко, M. A. (2001). Personalizm. Noveyschyi philosophskyi slovar. Mn.: Interpresservis. Kniznyi dom: 740-741. (In Russian)

Mościszko M. (2019). Surrealistyczny obraz piekła w poezji Wasyla stusa na podstawie zbioru wesoły cmentarz. Slavia Orientalis: 68 (1): 89-99. DOI: 10.24425/slo.2019.126548. (In Polish)

Onikiyenko, I. (2012). Vasyl Stus ta Yohann Volfhanh Gethe: dialoh pro megi ludstva. Visnyk Cherkaskoho universytetu. № 40 (253): 67-73. (In Ukrainian)

Plusch, L. (1986). Tam, livishe sertsya... Vbyvstvo poeta. Suchasnist. № 1. Traven. Ch. 5(301): 93-110. ( In Ukrainian)

Plusch, L. (1987). Vbyvstvo poeta V. Stusa. V. Stus $v$ zhytti, tvorchosti i spohadah ta ozinkah suchasnykiv. Baltymor; Toronto: Vyd.vo "Smoloskyp": 285-301. (In Ukrainian)

Plusch, L. (1988). V mene uzhe narodjuetsya Boh. Retrieved from http://www.jimagazine.Iviv.ua/Promovy_laureativpremii Antonovychiv/Plyusch.htm (In Ukrainian)

Punina, O. (2016). "Za chytannyam Jasunari Kavabaty" Vasylya Stusa: Dosvid osyayannya. In O. Solovii, O. Punina (Ed.), Stusovi zoshyty: Naukovyi almanah. Zoshyt pershyi. Vinnytsya: Prostir Literatury, 120 p. (In Ukrainian)

Scharhovska, O. (2011). Leonid Plusch: "Socrealizm duzhe lehko pereishov u nacrealizm". Bibliotechka Dyvoslova. № 5: 2327. ( In Ukrainian)

Schevelov, Yu. (1986). Trunok i trutyzna. Pro Palimpsesty Vasylya Stusa. Palimpsesty. Virshi 1971 - 1979 rokiv. Nyu-york: vyd. Suchasnist, 486: 17-58. (In Ukrainian)

Soldatov, S. (1986). Pamyati Vasylya Stusa. Suchasnist. Ch. 5: 122-125 (In Ukrainian)

Solovei, O. (2016). Modusy hudozhnyoyi prozy Vasylya Stusa. In O. Solovii, O. Punina (Ed.), Stusoznavchi zoshyty: Naukovyi almanah: Zoshyt pershyi. Vinnytsya: Prostir Literatury: 96105. (In Ukrainian)

Stus, V. (1990). Depersonalizatsiya dushi. Vyzvolnyi shlyah. kn.3(504). Berezen: 319. (In Ukrainian)

Stus, D. (1992). Zhyttya i tvorchist Vasylya Stusa. Kyiv: MP Fotovideoservic, 87 p. (In Ukrainian)

Stus, V. (1992). Lyst do pershoho secretarya ZK Kompartiyi Ukrainy P. Yu. Shelesta. Lysty iz Slidchoho izolyatora: [Pislya serpnevyh podiy lysty V. Stusa, adresovani todishnyomu kerivnyztvu ZK Kompartiyi Ukrainy, iz spezhovu peredani na derzh]. Zberihannya do Zentr. Arhivu gromads. objednan Ukrainy. Polityka i Chas. № 1: 82-87. (In Ukrainian)

Stus, V. (1994). Tvory. In V. Stus, Tvory: u 4 t., t.6. kn.1. Lviv: Vyd. Spilka Prosvita, 544 p. (In Ukrainian) 
Stus, V. (2008). Otak ghyvu: yak mavpa sered mavp. In V. Stus, Taborovyi zoshyt. Vybrani tvory. Kyiv: Fakt: 28. (In Ukrainian)

Stus, V. (2008). Pahlo vesnoyu i priloyu hlytseyu. In V. Stus, Zibrannya tvoriv: $u 12$ t. T.3. Chas tvorchosti. DICHTENSZEIT. Kyiv: Fakt, 752 p. (In Ukrainian)

Stus, V. (2008). V meni ughe narodjujetsya Boh... In H. Burlaka, D. Stus (compiler), Zibrannya tvoriv: u 12 t. T.3: Chas tvorchosti. DICHTENSZEIT. Kyiv: Fakt, 752 p. (In Ukrainian)

Stus, V. (2008). O Bozhe tyshi day. In V. Stus, Zibrannya tvoriv: u
12 t. T.3: Chas tvorchosti. DICHTENSZEIT. Kyiv: Fakt, 752 p. (In Ukrainian)

Stus, V. (2008). U nebi zori. In V. Stus, Zibrannya tvoriv: u $12 t$. T.3: Chas tvorchosti. DICHTENSZEIT. Kyiv: Fact, 752 p. (In Ukrainian)

Tarnashynska, L. (2001). Prostir avtorovoho isnuvannya $v$ interpretatsiyi Vasylya Stusa. Actualni problemy ukrainskoyi literatury $i$ folkloru. Donetsk: vyd-vo Donetskoho natsionalnoho universytetu. Vyp. 6: 144-151. (In Ukrainian)

Роксолана Вербова,

Київський хореографічний коледж (м. Київ, Украӥна)

e-mail: rverbova@gmail.com,ORCID 0000-0003-4653-6057

\section{САМОВДОСКОНАЛЕННЯ ОСОБИ КРІЗЬ ПРИЗМУ ПІЗНАННЯ БОГА УПОЕЗІЯХ ВАСИЛЯ СТУСА}

У статті проведено аналіз персоналістських ідей Василя Стуса 3 точки зору християнської філософії. Закцентовано увагу на самовдосконаленні особи в контексті пізнання Бога як однієї з головних проблем у творчості українського мислителя. У дослідженні висвітлено актуальні питання, пов'язані із внутрішнім світом людини та впливом духовності на формування особи. Простежено тенденцію до розкриття тематики персоналістського діалогу Бога і особи у поезіях Василя Стуса. Розкрито проблему становлення особистісної свободи крізь призму пізнання Бога. Розглянуто медитацію як один із станів самопізнання Бога кожною конкретною особою. Доведено, що у творчості українського поета взаємозв'язок особи і Бога має значення і у відбитті індивідуального авторського модусу буття, і у формуванні більш загального виявлення відповідної персоналістської рецепції. Використано персоналістський метод, який є універсальним засобом пізнання людини і всієї реальності.

Ключові слова: християнський персоналізм; самовдосконалення особи; самопізнання особи; персоналістські ідеї В. Стуса; персоналізація молитви.

(C) Roksolana Verbova

Надійшла до редакції: 05.05.2020

Прийнята до друку: 10.06.2020 